\title{
The Activities of Glutamate Dehydrogenases during Mycelial Growth and Sporophore Development in Coprinus lagopus (sensu Lewis)
}

\author{
By G. R. STEWART AND D. MOORE \\ Department of Botany, The University, Manchester $M{ }_{13} 9 P L$
}

(Received 2I November 1973; revised 2I February 1974)

\begin{abstract}
SUMMARY
The activity of the NADP-linked glutamate dehydrogenase $\left(\mathrm{GDH}_{\mathrm{NADP}}\right)$ increased in the pileus during sporophore development but remained at a low level in the parent mycelium and in the sporophore stipe. In contrast, the NAD-linked enzyme $\left(\mathrm{GDH}_{\mathrm{XD}}\right)$ increased in mycelium, stipe and pileus. It is suggested that the increase in $\mathrm{GDH}_{\mathrm{VADP}}$ activity is a developmental phenomenon. In vegetative mycelia the two GDH enzymes appeared to be regulated reciprocally; $\mathrm{GDH}_{\mathrm{NAD}}$ was subject to catabolite repression and urea derepression, while $\mathrm{GDH}_{\mathrm{NADP}}$ was catabolite derepressed and repressed by urea. It is suggested that $\mathrm{GDH}_{\mathrm{NAD}}$ may be the enzyme normally involved in ammonia assimilation, $\mathrm{GDH}_{\mathrm{XADP}}$ being reserved for specific functions associated with developmental alterations in metabolism.
\end{abstract}

\section{INTRODUCTION}

The development of the sporophore of the Basidiomycete fungus Coprinus lagopus $(=C$. cinereus) provides an elegant model system for studies of morphogenesis. This complex and highly organized structure arises from a relatively simple mycelium and is composed of recognizable hyphal elements. The tissues of the sporophore, the parent mycelium and the physical and chemical events which promote and accompany the formation of sporophores are all amenable to study in a variety of ways. Recently there has been a number of investigations into the biochemical changes which underlie sporophore formation. Rao \& Niederpruem (I969) demonstrated differences in the metabolism of polyols in the cap and stipe, while Gooday (I972) investigated the biochemical events underlying stipe expansion. Iten \& Matile (1970) showed that there is an ordered sequence of events, including the formation and release of hydrolytic enzymes, leading up to the cap autolysis which is such an obvious feature of this genus. We have concentrated on a search for changes in metabolism during the initiation and early development of sporophores. In this paper the changes which occurred in the activities of glutamate dehydrogenases are reported and an attempt is made to correlate the changes with the regulation of these enzymes in vegetative mycelia (Fawole \& Casselton, 1972).

\section{METHODS}

Organism and culture techniques. Two monokaryotic strains of Coprinus lagopus (sensu Lewis) $[=C$. cinereus (Schaeff. ex Fr.) S. F. Gray] were used. They had the stock numbers HI (mating type $A_{5} B_{5}$ ) and $\mathrm{BC}_{9} / 6,6$ (mating type $\mathrm{A}_{6} \mathrm{~B}_{6}$ ). Their joint dikaryon was used for the production of sporophores.

A defined basal medium (SNC) was used for liquid growth tests. It consisted of (mM): $\mathrm{Na}_{2} \mathrm{HPO}_{4},{ }_{10} ; \mathrm{KH}_{2} \mathrm{PO}_{4}, \mathrm{I}_{0} ; \mathrm{Na}_{2} \mathrm{SO}_{4}, 2 ; \mathrm{MgSO}_{4}, 0.5$; and thiamin hydrochloride, 0.003 . 
Table I. Developmental stages of Coprinus lagopus sporophores

$\begin{array}{cc}\text { Time of } \\ \text { Stage number } & \begin{array}{c}\text { appearance } \\ \text { (days from } \\ \text { and trivial name }\end{array} \\ \text { inoculation) }\end{array}$
o. Initials
$4 \cdot 2-8 \cdot 4$

I. Primordia

$5 \cdot 7-9 \cdot 1$

2. Primordia

3. Immature fruits

$7 \cdot \mathrm{I}-10 \cdot 3$

4. Immature fruits

$7 \cdot 7-10 \cdot 9$

5. Mature fruits

$8 \cdot \mathrm{I}-\mathrm{I} 3 \cdot 7$
White-cream coloured spheres or egg shapes up to $2 \mathrm{~mm}$ in diam. Some suggestion of differentiation occasionally, but never very clear.

White-cream coloured spheres or egg shapes, 2-6 $\mathrm{mm}$ in height. In the larger samples the cap can be distinguished externally and surgically removed. Gill tissues well developed, but basidia (about $12 \mu \mathrm{m}$ long) not fully differentiated. Karyogamy occurs towards the end of this stage.

6.3-9.9 White, 6-9 $\mathrm{mm}$ in height. Volva intact initially but becoming more or less free by the end of this stage. Gills beginning to separate, with cystidia about $45 \mu \mathrm{m}$ long. Basidia about I5-I $8 \mu \mathrm{m}$ long. Meiosis occurs during this stage.

White, over $10 \mathrm{~mm}$ in height; volva free. The stipe, clearly separated from the cap, begins to elongate slowly. Hymenium fully differentiated; cystidia about $60 \mu \mathrm{m}$ long. Meiosis complete; basidia (about $20 \mu \mathrm{m}$ long) begin to form sterigmata and spores. A transient stage that can only be recognized with confidence by dissection and microscopic examination.

Height $15-53 \mathrm{~mm}$ (average $26.6 \mathrm{~mm}$ ). Colour varies from white to dark grey as this stage covers the final maturation pigmentation of the spores. Stipe continues to elongate slowly
Height $19-93 \mathrm{~mm}$ (average $45.5 \mathrm{~mm}$ ). This stage is heralded by the rapid elongation of the stipe. Spore discharge begins and as it continues the cap opens out and autolyses.

Carbon and nitrogen sources were added as appropriate and the final $\mathrm{pH}$ of the medium was $6 \cdot 8$. Dikaryons intended for fruiting were grown on horse dung or a liquid medium (maltose-CM) which was derived from basal medium SNC by the addition of $(\mathrm{g} / \mathrm{l})$ : maltose, 5; glucose, 4; asparagine, 2; ammonium tartrate, 0.5; Difco malt extract, I ; Difco yeast extract, 0.7 ; and Difco Casamino acids, 0.7. The effect of the medium on sporophore development was studied by transferring immature sporophores to a transfer medium identical in composition to the SNC medium but with the $\mathrm{pH}$ adjusted to 7.9 . Carbon and nitrogen sources were added as described in the text. A pH of $7 \cdot 9$ was used since this is the value attained in the normal medium about the time of sporophore production (Fig. 3).

Vegetative mycelium was grown in $20 \mathrm{oz}$ medical flats (containing Ioo ml liquid medium) inoculated with suspensions of oidia and incubated statically for 3 to 5 days at $37^{\circ} \mathrm{C}$. Fruiting cultures were grown in crystallizing dishes containing dung or liquid maltose-CM ( $100 \mathrm{ml} / \mathrm{dish}$ ). The latter were inoculated by floating pieces of mycelium on the medium. The cultures were incubated statically at $37{ }^{\circ} \mathrm{C}$ in the dark for 3 (dung) or 4 (maltose-CM) days and then transferred to an illuminated growth room (continuous illumination, 700 lux) at 26 to $28{ }^{\circ} \mathrm{C}$. To determine the effect of a change in nutritional environment on sporophore development, immature sporophores were removed from cultures grown on dung. Petri dishes of transfer medium solidified with agar were prepared by cutting wells in the agar. The sporophores were placed with the bases of their stipes in the wells and were fixed in position with a 'mortar' of molten agar medium. The plates were then covered with crystallizing dishes and incubated in the dark at $26{ }^{\circ} \mathrm{C}$. Transferred sporophores were harvested 

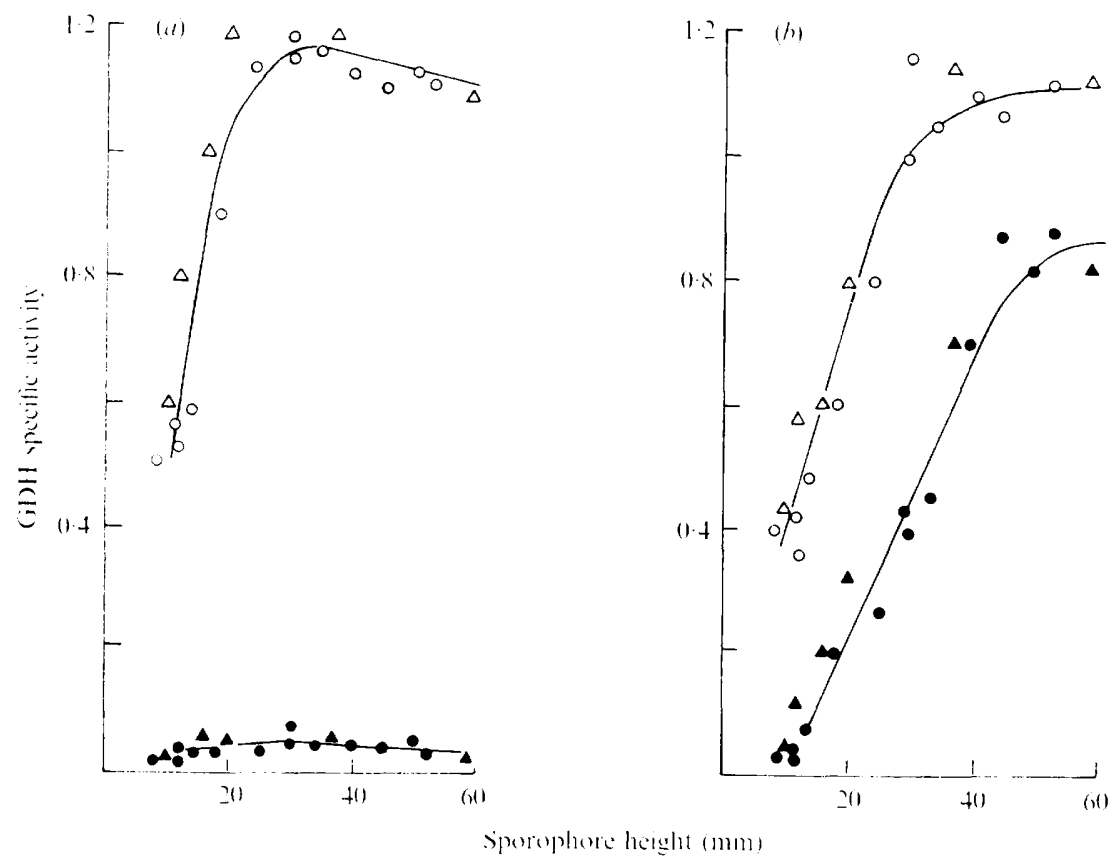

Fig. I. Specific activities of $\mathrm{GDH}_{\mathrm{XAD}}$ (open symbols) and $\mathrm{GDH}_{\mathrm{NADP}}$ (solid symbols) in the stipes $(a)$ and caps $(b)$ of sporophores of different sizes. Sporophores were grown either on dung (triangles) or maltose-CM (circles). Sporophore height is a rough guide to the developmental stage (see Table 1).

for enzyme analysis when they began to discharge basidiospores about Io to $\mathrm{I} 2 \mathrm{~h}$ later. This technique was uniformly successful with sporophores transferred at stage 4 (see Table I); transfer at earlier stages has not yet proved sufficiently reliable to be of use.

Enzyme extraction and assay. Enzyme extracts were prepared as described previously (Stewart \& Moore, 1971); in the present experiments the extraction buffer was O.I Mphosphate, $\mathrm{pH} 7 \cdot 5$. Glutamate dehydrogenase $(\mathrm{GDH})$ was assayed as reductive amination by measuring the decrease in $E_{340}$ on oxidation of NADH or NADPH using a Pye-Unicam SPI800 recording spectrophotometer. The assay medium for the NAD-specific enzyme

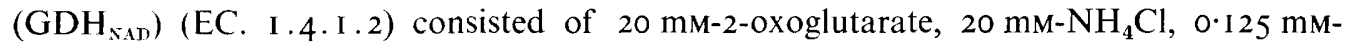
$\mathrm{NADH}$, IoO mM-phosphate buffer $\mathrm{pH} 8 \cdot 2$. That for the NADP-specific enzyme $\left(\mathrm{GDH}_{\mathrm{XADP}}\right)$ (EC. I.4. I.4) was the same except that 0.I25 mM-NADPH was substituted for the NADH and the $\mathrm{pH}$ was adjusted to $7 \cdot 5$. In each case the final volume of the reaction mixture was $2.5 \mathrm{ml}$ and the assay temperature was $30^{\circ} \mathrm{C}$. Protein was determined as before (Stewart \& Moore, 1971).

Expression of results. Enzyme activities are expressed as $\mu$ mol NADH or NADPH oxidized $/ \mathrm{min} / \mathrm{mg}$ protein. In descriptions of the developing sporophore, changes in enzyme level are given as a function of the length of the stipe. This has been used as an arbitrary indicator of the developmental stage of the sporophore. The morphological and cytological characteristics of the different developmental stages recognized and referred to in this paper are summarized in Table $\mathrm{I}$. 


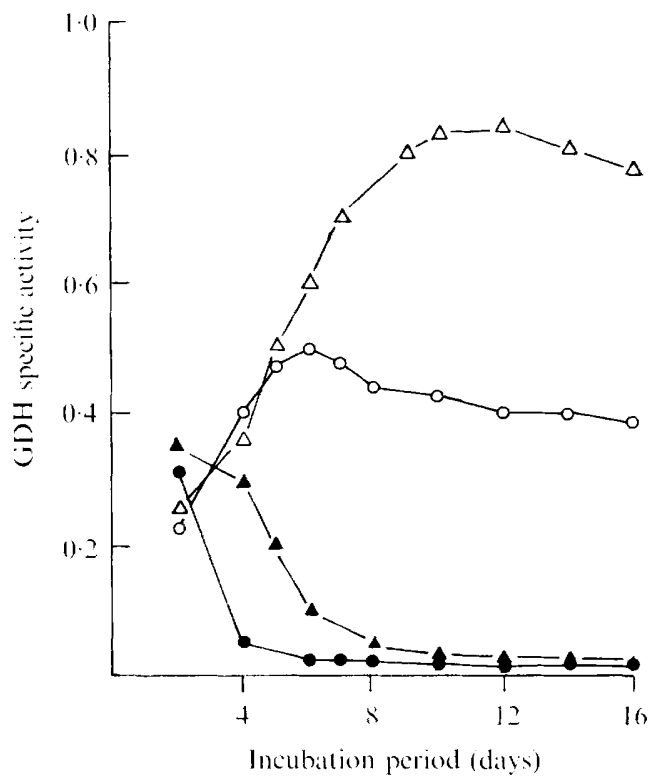

Fig. 2. Specific activities of $\mathrm{GDH}_{\mathrm{NAD}}$ (open symbols) and $\mathrm{GDH}_{\mathrm{NADP}}$ (solid symbols) in mycelia of the $\mathrm{BC} 9 / 6,6 \times \mathrm{HI}$ dikaryon (circles) and of the $\mathrm{BC} / 6,6$ monokaryon (triangles) grown statically on maltose-CM medium using the temperature and light regime described for fruiting cultures.

\section{RESULTS}

GDH levels during sporophore development

The changes which occurred in the activities of the two forms of GDH during cap and stipe development are shown in Fig. I. The difference in behaviour of $\mathrm{GDH}_{\mathrm{NADP}}$ between cap and stipe is very striking. A low but constant activity at all stages of stipe elongation was accompanied by a 50 -fold increase in the $\mathrm{GDH}_{\mathrm{NADP}}$ in the caps which were removed from those stipes. In contrast, there was a twofold increase in $\mathrm{GDH}_{\mathrm{NAD}}$ in both cap and stipe during growth from primordium to mature sporophore. An identical pattern was obtained whether the sporophores were obtained from cultures on dung or on maltose-CM, suggesting that the change in pattern of the two GDH enzymes is a developmental character rather than a response to the nutritional environment.

Response to the nutritional environment, however, was seen in the changes in GDH activities during the early growth of the dikaryotic mycelium (Fig. 2). There was a marked decline in the activity of $\mathrm{GDH}_{\mathrm{NADP}}$ from the second to the sixth day. In contrast, the level of $\mathrm{GDH}_{\mathrm{XAD}}$ continued to rise up to the seventh day and only from about the eighth day of incubation did it attain a fairly constant level. These changes in the dikaryon GDH spectrum were probably associated with alterations in the medium (summarized in Fig. 3) during growth of the colony since the enzymes in mycelium of the monokaryon $\mathrm{BC} 9 / 6,6$ showed a similar pattern when grown under similar conditions. The rise in $\mathrm{GDH}_{\mathrm{NAD}}$ was, however, greater in the monokaryon and did not level off until about the eleventh day.

The simplest explanation for the difference in activity of $\mathrm{GDH}_{\mathrm{XADP}}$ in cap and stipe is that the enzyme is present in the basidiospores or is associated with spore formation. Dissection of the cap into gill-tissue and basidiospores (Table 2) indicated that $\mathrm{GDH}_{\mathrm{XADP}_{\mathrm{A}}}$ is almost exclusively found in the gill-tissue. This restriction of $\mathrm{GDH}_{\mathrm{xaDP}}$ to the gills does not rule out 


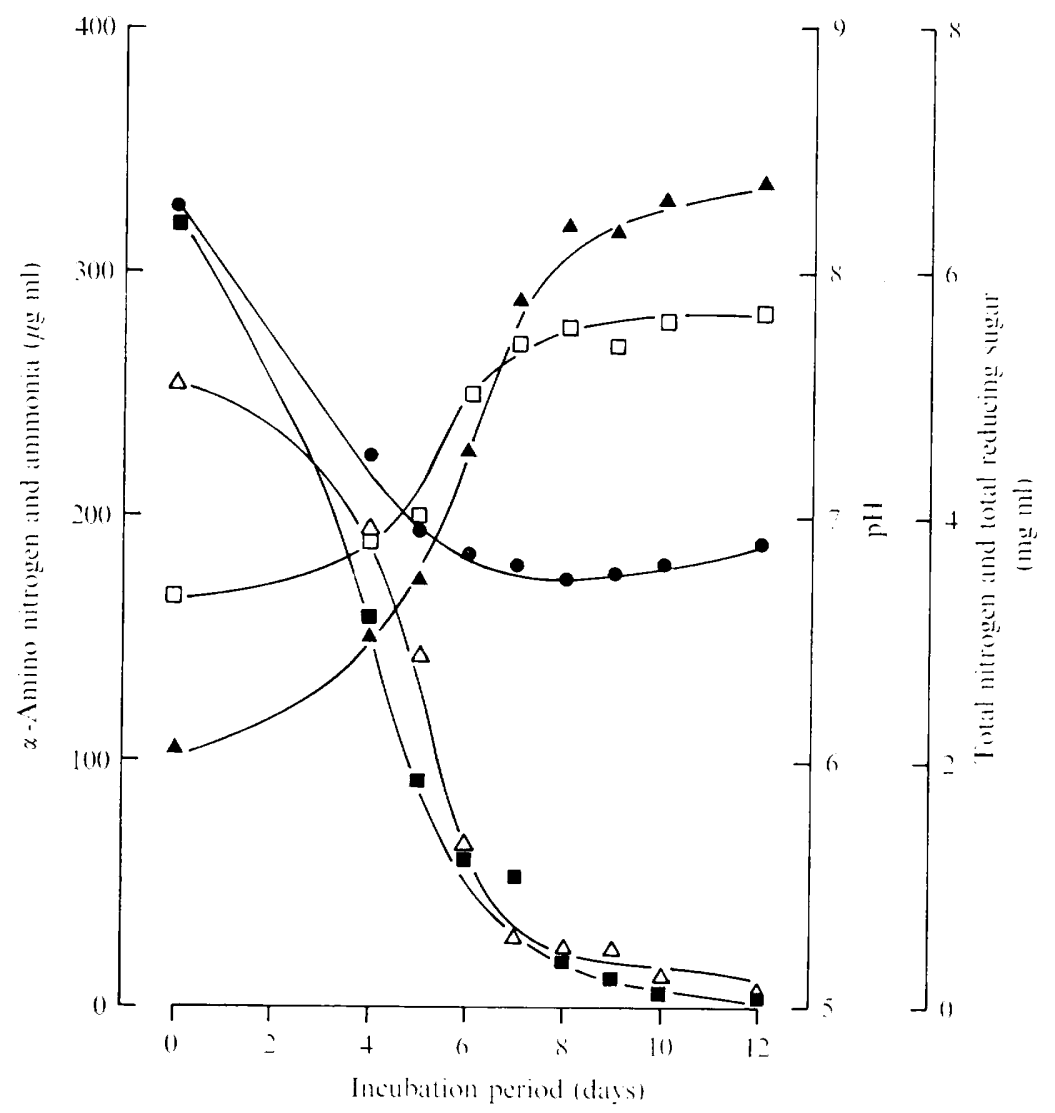

Fig. 3. Changes which occur in maltose-CM medium during growth of a dikaryon which is producing sporophores. The first sporophore initials are seen after about 4 days, primordia after about 7 , meiosis occurs at about the 8 th day, spores are pigmented at about the 9 th day and spore discharge and cap autolysis commence at day Io. $\boldsymbol{\square}$, Total reducing sugar; $\triangle, \alpha$-amino nitrogen; $\Delta$, ammonia; $\bullet$, total nitrogen;,$- \mathrm{pH}$.

Table 2. Typical specific activities of glutamate dehydrogenases in various parts of the mature sporophore

Mature sporophores were dissected and their component parts assayed separately.

\begin{tabular}{|c|c|c|c|c|}
\hline \multirow[b]{3}{*}{ Tissue } & \multicolumn{4}{|c|}{ Enzyme activities $(\mu \mathrm{mol} / \mathrm{min} / \mathrm{mg}$ protein) } \\
\hline & \multicolumn{2}{|c|}{$\mathrm{GDH}_{\mathrm{XAD}}$} & \multicolumn{2}{|c|}{$\mathrm{GDH}_{\mathrm{NADP}}$} \\
\hline & Dung & Maltose-CM & Dung & Maltose- $\mathrm{CM}$ \\
\hline Stipe & $I \cdot 14$ & $I \cdot 2 I$ & 0.06 & 0.06 \\
\hline Cap (entire) & 1.04 & $\mathrm{I} \cdot \mathrm{I} 4$ & 0.84 & 0.73 \\
\hline Gill tissue & 0.93 & $1 \cdot 07$ & 0.98 & 0.82 \\
\hline Basidiospores & $0 \cdot 34$ & 0.32 & 0.04 & 0.05 \\
\hline
\end{tabular}


Table 3. Specific activities of glutamate dehydrogenases of monokaryotic mycelium grown in various liquid media

Mycelia of the monokaryon strain BC9/6,6 were grown on the appropriate media in still culture and assayed after 3 to 5 days' incubation at $37^{\circ} \mathrm{C}$.

\begin{tabular}{|c|c|c|c|}
\hline \multicolumn{2}{|c|}{ Medium } & \multicolumn{2}{|c|}{$\begin{array}{c}\text { Enzyme activity } \\
(\mu \mathrm{mol} / \mathrm{min} / \mathrm{mg} \text { protein })\end{array}$} \\
\hline Carbon source & $\begin{array}{l}\text { Nitrogen source } \\
\quad(25 \mathrm{~mm})\end{array}$ & $\mathrm{GDH}_{\mathrm{XAD}}$ & $\mathrm{GDH}_{\mathrm{NAIP}}$ \\
\hline $25 \mathrm{~mm}$-Acetate & $\begin{array}{l}\text { Ammonia } \\
\text { Asparagine } \\
\text { Glutamate } \\
\text { Serine } \\
\text { Urea }\end{array}$ & $\begin{array}{l}0.66 \\
0.53 \\
I \cdot 3 I \\
0 \cdot 72 \\
I \cdot 12\end{array}$ & $\begin{array}{l}0.01 \\
0.09 \\
0.01 \\
0.09 \\
0.01\end{array}$ \\
\hline $44 \mathrm{~mm}-$ Glucose & $\begin{array}{l}\text { Ammonia } \\
\text { Asparagine } \\
\text { Glutamate } \\
\text { Glutamine } \\
\text { Urea }\end{array}$ & $\begin{array}{l}0.97 \\
0.43 \\
0.31 \\
0.52 \\
1.14\end{array}$ & $\begin{array}{l}0.16 \\
0.10 \\
0.26 \\
0.20 \\
0.03\end{array}$ \\
\hline $88 \mathrm{~mm}-$ Glucose & $\begin{array}{l}\text { Ammonia } \\
\text { Asparagine } \\
\text { Glutamate } \\
\text { Glutamine } \\
\text { Urea }\end{array}$ & $\begin{array}{l}0.23 \\
0.50 \\
0.33 \\
0.27 \\
I .25\end{array}$ & $\begin{array}{l}0.31 \\
0.28 \\
0.48 \\
0.30 \\
0.05\end{array}$ \\
\hline
\end{tabular}

a role for it in the metabolic processes associated with spore formation. However, the tissue used had almost mature spores and the increase in $\mathrm{GDH}_{\mathrm{NADP}}$ activity in the cap was out of phase with the development of the spores. So it is unlikely that $\mathrm{GDH}_{\mathrm{NADP}}$ has a role in anything other than a late step in spore development if it is involved in that process at all.

\section{Regulation of GDH in vegetative mycelium}

The level of both enzymes was markedly influenced by the nature and concentration of the carbon source (Table 3). On all nitrogen sources the activity of $\mathrm{GDH}_{\mathrm{NADP}}$ was higher when the mycelium was grown on glucose than when grown on acetate, and the activity increased as the glucose concentration was increased. Conversely, the level of $\mathrm{GDH}_{\mathrm{NAD}}$ was lower on glucose than on acetate. The nature of the nitrogen source had much less influence on the two enzymes. These data suggest that $\mathrm{GDH}_{\mathrm{XAD}}$ is subject to catabolite repression while $\mathrm{GDH}_{\mathrm{NADP}}$ is derepressed or induced by glucose or some product of glucose metabolism. These data and conclusions are in accord with those presented by Fawole \& Casselton (1972), who considered that if a product of glucose metabolism (possibly 2-oxoglutarate) was responsible for the concurrent and reciprocal regulation of the two GDH enzymes then the complete system of regulation must involve more than one molecular species. The second regulator could well be, or be derived from, urea. Fawole \& Casselton (1972) did not investigate the effects of urea but it is clear from Table 3 that this molecule has a profound effect on the GDH enzymes, causing repression of $\mathrm{GDH}_{\mathrm{NADP}}$ and derepression of $\mathrm{GDH}_{\mathrm{NAD}}$. Moreover, this effect is exerted independently of the carbon source. Regulation of the mycelial, but not the sporophore, GDH enzymes could presumably be accounted for by changes in the balance of these two metabolites. With the mycelial enzymes, metabolites which increased the level of one generally also reduced the level of the other, but during cap expansion the activity of both enzymes increased. 


\section{Table 4. Specific activities of glutamate dehydrogenases in sporophores transferred to different substrates}

Sporophores at developmental stage 4 were removed from cultures growing on dung, some were immediately assayed, the rest were transferred to the media indicated and then assayed about I $2 \mathrm{~h}$ later when they had developed to stage 5 .

\begin{tabular}{|c|c|c|c|c|}
\hline \multirow[b]{3}{*}{ Treatment } & \multicolumn{4}{|c|}{ Enzyme activity $(/ \mathrm{mol} / \mathrm{min} / \mathrm{mg}$ protein) } \\
\hline & \multicolumn{2}{|c|}{ Stipe tissue } & \multicolumn{2}{|c|}{ Cap tissue } \\
\hline & $\mathrm{GDH}_{\mathrm{NAD}}$ & $\mathrm{GDH}_{X A \cup \Gamma}$ & $\mathrm{GDH}_{\mathrm{N}+\mathrm{I}}$ & $\mathrm{GDH}_{\mathrm{NALl}}$ \\
\hline $\begin{array}{l}\text { Freshly harvested } \\
\text { Sporophores transferred to medium } \\
\text { containing: }\end{array}$ & 0.89 & 0.04 & 0.64 & $0 \cdot 25$ \\
\hline $5 \mathrm{~mm}-$ Glucose $+25 \mathrm{~mm}-\mathrm{NH}_{4} \mathrm{Cl}$ & $1 \cdot 15$ & 0.05 & $I \cdot 12$ & 0.81 \\
\hline $5 \mathrm{~mm}-$ Glucose $+25 \mathrm{~mm}$-urea & $\mathrm{I} \cdot 24$ & 0.05 & $I \cdot I I$ & 0.90 \\
\hline $88 \mathrm{~mm}-$ Glucose $+25 \mathrm{~mm}-\mathrm{NH}_{4} \mathrm{Cl}$ & $1 \cdot 26$ & 0.04 & $\mathrm{I} \cdot 27$ & 0.99 \\
\hline
\end{tabular}

\section{Regulation of $G D H$ in sporophores}

The effect of compounds which act as inducers and repressors of GDH in the monokaryon was investigated in developing sporophores. Immature sporophores were transferred to media which might be expected to induce $\mathrm{GDH}_{\mathrm{AAPD}}$ in the stipe and repress it in the cap. All of the transferred sporophores continued their development after transfer and they were harvested for enzyme analysis when they began to discharge spores. Transfer to a glucoseammonium medium failed to induce $\mathrm{GDH}_{\mathrm{NADP}}$ in the stipe (though it did so in mycelia) and transfer to a medium containing $25 \mathrm{~mm}$-urea failed to repress it in the cap but did so in mycelia (Table 4 ).

\section{DISCUSSION}

We have confirmed the observations of Fawole \& Casselton (1972) that in vegetative mycelia of Coprinus lagopus $\mathrm{GDH}_{\mathrm{NAD}}$ is subject to catabolite repression and $\mathrm{GDH}_{\mathrm{XADP}}$ to catabolite derepression. Fawole \& Casselton (1972) observed that glutamate could overcome this catabolite regulation to a limited extent. The marked influence of urea observed in the present experiments indicates that other 'nitrogenous' metabolites can have a similar effect. It seems, therefore, that regulation of the GDH enzymes in vegetative mycelia might be accounted for by the assumption that it depends on the action of at least two metabolites, one of which can broadly be referred to as being a product of carbon metabolism, the other as a product of nitrogen metabolism. The activity of the GDH enzymes in dikaryotic mycelia which were producing sporophores can be accounted for in these terms. The decline in $\mathrm{GDH}_{\mathrm{NAPD}}$ and concomitant increase in $\mathrm{GDH}_{\mathrm{NAD}}$ could have been a direct response to reductions in catabolite pools as the colony matured to the stage when sporophore production is initiated. However, the changes in enzyme activity that occurred in the sporophore itself cannot be explained in these terms. Both enzymes increase in activity in the cap, a situation that has never been observed in these experiments in mycelium. Moreover, the failure of sporophore transfer to an acetate-urea medium to repress, and to glucose-ammonium medium to induce, $\mathrm{GDH}_{\mathrm{XADP}}$ in the cap and stipe respectively also argues against the use of this simple metabolite-regulation model to explain the situation in the sporophore. Nor can the negative results of these experiments be ascribed to any failure of the stipe to take up the supplied metabolites. Stipes harvested after transfer to glucose-ammonium medium have been found to have glucose and ammonia pools at least 3 to 4 times greater than controls 
Table 5. Comparison of specific activities of glutamate dehydrogenases and mycelial growth of the monokaryon $\mathrm{BC} 9 / 6,6$ cultured on contrasting media

Mycelia were grown in still culture in the appropriate media and assayed after 4 days' incubation at $37^{\circ} \mathrm{C}$.

\begin{tabular}{|c|c|c|c|c|}
\hline \multirow[b]{2}{*}{ Medium } & \multicolumn{2}{|c|}{$\begin{array}{c}\text { Enzyme activity } \\
(\mu \mathrm{mol} / \mathrm{min} / \mathrm{mg} \text { protein })\end{array}$} & \multirow{2}{*}{$\begin{array}{c}\text { Extension } \\
\text { growth rate } \\
(\mathrm{mm} / \mathrm{h})\end{array}$} & \multirow{2}{*}{$\begin{array}{c}\text { Niycelium dry } \\
\text { weight yield } \\
\text { (mg/100 ml } \\
\text { medium) }\end{array}$} \\
\hline & $\mathrm{GDH}_{\mathrm{NAT}}$ & $\mathrm{GDH}_{\mathbb{N A D P}}$ & & \\
\hline $25 \mathrm{~mm}$-Acetate $+25 \mathrm{~mm}$-urea & $\mathbf{I} \cdot 77$ & 0.05 & $0 \cdot 382$ & $24 \cdot 4$ \\
\hline $\begin{array}{l}25 \mathrm{~mm} \text {-Acetate }+25 \mathrm{~mm}- \\
\text { glutamate }\end{array}$ & 2.07 & 0.07 & 0.207 & $25^{\circ} 9$ \\
\hline Dung extract & $2 \cdot 19$ & 0.00 & 0.446 & $43 \cdot 2$ \\
\hline
\end{tabular}

(G. R. Stewart, unpublished). Also, Gooday (1972) has shown that polyoxin D, an inhibitor of chitin synthetase, totally prevents the elongation of excised sporophores; so the stipe does seem to have the ability to take up a range of applied compounds.

There is no evidence that cap- and stipe-specific isoenzymes are produced which are under the control of a system independent of that which regulates mycelial enzymes. Cellulose acetate and polyacrylamide gel electrophoresis have failed to reveal any differences in the GDH enzymes of cap, stipe or mycelium. Only a single form of each type of GDH can be detected.

If repression operates at the level of transcription then the failure to detect repression of $\mathrm{GDH}_{\mathrm{NADS}}$ in the cap might be because the structural gene involved has been fully transcribed prior to transfer; similarly it could be suggested that the same gene is unavailable for transcription in stipe tissue and so makes induction of $\mathrm{GDH}_{\mathrm{NaDp}}$ in that tissue impossible. Similar situations have been recognized during development of several organisms (Sterlini \& Mandelstam, 1969; Ashworth, I97I) but these suggestions succeed only in removing the regulatory event to a different level and do not explain why the two GDH enzymes appear to be regulated reciprocally in mycelium but not in the cap.

It is sometimes supposed that in organisms which possess both a NAD- and a NADPlinked GDH both enzymes are components of normal metabolism but have different functions, $\mathrm{GDH}_{\mathrm{NAD}}$ having a catabolic role while $\mathrm{GDH}_{\mathrm{XADP}_{\mathrm{ADP}}}$ serves an anabolic function. As a consequence of this the two enzymes are reciprocally regulated, and metabolites which increase the activity of one reduce the other (Goldin \& Frieden, 197 I). Some of the difficulties in interpretation of the evidence on this subject are discussed by Casselton (1969), Goldin \& Frieden (I97I) and Fawole \& Casselton (I972). Data obtained with basidiomycetes seem to conflict with these assumptions. There is evidence from this study (Table 5) that $\mathrm{GDH}_{\mathrm{NAD}}$ is capable of serving both anabolic and catabolic functions, since it is the major enzyme in the mycelium whether it is grown on acetate-urea medium which demands that nitrogen be obtained by amination or on acetate-glutamate medium which requires deamination. $\mathrm{GDH}_{\mathrm{NADP}}$ can be demonstrated by experimental manipulation of the medium, but it is clear that the highest levels of $\mathrm{GDH}_{\mathrm{NADP}}$ observed in the mycelium are only seen on very unusual media. Thus the highest mycelial $\mathrm{GDH}_{\mathrm{NADP}}$ activities require very high glucose concentrations and the absence of urea. It is difficult to envisage the organism meeting with such conditions in the wild. Coprinus is a coprophilous organism and the closest approach we can make to growing mycelium on a natural substrate is to use dung extract. Analyses of mycelia grown in this way are also shown in Table 5. Good growth is made on all three media. From this Table we conclude that under natural conditions of mycelial growth the major, 
perhaps the only, GDH enzyme present is $\mathrm{GDH}_{\mathrm{x} \text { aD }}$, and that this enzyme alone is capable of supporting adequate growth whether it is operating in the direction of amination or deamination. We have already indicated that the only natural situation so far known in which $\mathrm{GDH}_{\mathrm{XADP}}$ activity is greatly increased is during sporophore formation. Thus $\mathrm{GDH}_{\mathrm{NAD}}$ may be a component of normal vegetative metabolism and $\mathrm{GDH}_{\mathrm{XAIP}}$ produced only in response to very unusual shifts in metabolism of the sort that might occur during morphogenetic changes. This model envisages the reciprocal regulation in mycelia to be a result of growth on a medium that is quite unusual so far as the ecological experience of the organism in the wild is concerned. The key to $\mathrm{GDH}_{\text {NADP }}$ regulation probably lies in its function in the cap. Involvement with spore formation seems unlikely since sterile fruits (sporophores which fail to produce spores but otherwise develop and autolyse normally) exhibit the same pattern of GDH behaviour as described for normal sporophores. However, spore discharge is not the end of the developmental sequence in Coprinus, as autolysis of the cap is an integral part of spore dispersal, and it is possible that $\mathrm{GDH}_{\mathrm{XADP}}$ is involved in these later metabolic changes.

\section{REFERENCES}

Ashworth, J. M. (197 I). Cell development in the cellular slime mould Dictyostelium discoideum. Symposia of the Society for Experimental Biology 25, 27-49.

Casselton, P. J. (1969). Concurrent regulation of two enzymes in fungi. Science Progress 57, 207-227.

Fawole, M. O. \& Casselton, P. J. (1972). Observations on the regulation of glutamate dehydrogenase activity in Coprinus lagopus. Journal of Experimental Botany 23, 530-55I.

Goldin, B. R. \& Frieden, C. (1971). L-Glutamate dehydrogenases. Current Topics in Cellular Regulation 4 , 77-117.

Gooday, G. (1972). The role of chitin synthetase in the elongation of fruit bodies of Coprinus cinereus. Journal of General Microbiology 73, xxi.

Iten, W. \& Matile, P. (1970). Role of chitinase and other lysosomal enzymes of Coprinus lagopus in the autolysis of fruiting bodies. Journal of General Microbiology 6r, 30I-309.

Rao, P.S. \& Niederpruem, D. J. (1969). Carbohydrate metabolism during morphogenesis of Coprinus lagopus (sensu Buller). Journal of Bacteriology 100, I 222-I 228.

Sterlini, J. M. \& Mandelstam, J. (1969). Commitment to sporulation in Bacillus subtilis and its relationship to development of actinomycin resistance. Biochemical Journal I13, 29-37.

Stewart, G. R. \& Moore, D. (1971). Factors affecting the level and activity of pyruvate kinase from Coprinus lagopus sensu Buller. Journal of General Microbiology 66, 361-370. 